\title{
College Conversion Into Quarantine Center: Parents Perception On Covid-19 Mitigation Measures At Kenya Medical Training College Mombasa
}

\author{
Garama Mramba, Jeniffer Mwema, Rachael Mwende, Florid Ogall, Lucas Ruwah \\ Bachelors, KMTC \\ DOI: 10.29322/IJSRP.10.10.2020.p10679 \\ http://dx.doi.org/10.29322/IJSRP.10.10.2020.p10679
}

\begin{abstract}
The purpose of the study was to determine perception of parents in regard to Covid-19 mitigation measures before and after resumption of learning activities in the college. Methodology: This study was carried out at KMTC-Mombasa using descriptive cross-sectional design. Participants (parents) were selected using multi stage sampling and convenient sampling technique was used. There was assumption that one student had one parent representation. The population of students was 850 and $10 \%$ of the students population was used $(0.1 \times 850 \mathrm{~N}=85),(\mathrm{p}=95 \%), \mathrm{n}=73$. Data was obtained using interviewer administered questionnaire. Data analysis was done using SPSS and Excel. The results were presented using tables, charts and narrations. Results: $54.8 \%$ (40) of the respondents were males and the dominant age bracket of the respondents was (50-59) $42.5 \%$ (31). For the measures to be taken before college reopens, $32.9 \%$ (24), recommended restructuring of the college to ensure social distancing as it is required by the Government of Kenya during this time of pandemic, 30.1\% (22) suggested provision of infection prevention measures (PPE, sanitizers and soaps) and stoppage of quarantine activities in the college and $28.8 \%$ (21) recommended fumigation of the college. After students had reported back, $47.9 \%$ (35) of the parents felt that infection prevention measures should be to maintained to mitigate spread of COVID-19. Unique contribution to Theory, practice and Policy: Parents are key stake holders in issues related to the learning institutions during this time of pandemic and so social distancing and infection prevention measures should be addressed before and after resumption of learning. Parent's opinions should therefore be considered if the students have to resume studies given that they are the main financier. When the institution management has addressed the implementation of these measures then the students will be safe from contracting COVID19.
\end{abstract}

Index Terms- COVID-19, Kenya Medical Training College, Mitigation, Mombasa, Perception, Quarantine centre

\section{INTRODUCTION}

$\mathrm{T}^{\mathrm{s}}$ he Corona Virus Disease of 2019 (COVID-19) pandemic is considered as the most crucial global health calamity of the century. In December 2019, the disease emerged in Wuhan, Hubei province, China. Kenya confirmed its' maiden case on 13th March 2020 after which the cases have continued to be on the increase.
As part of containment measures the World Health Organization (WHO) on 29th February 2020 introduced quarantine as a control measure which was then adopted by the Government of Kenya in which selected learning institutions and hotels were temporarily converted into COVID-19 quarantine centers. Kenya Medical Training College Mombasa was one of the learning institutions converted into COVID-19 quarantine centre where the study was conducted.

The COVID-19 pandemic has caused great disruptions of education systems in history by affecting about 1.6 billion learners in more than 190 countries in the whole world. Closing of schools has impacted 94 percent of the world's student population and about 99 percent in low and lower middle income countries. In this regard there is need to listen to the voices of all concerned persons. Considering the role that parents, caretakers and teacher played since the onset of crisis an essential part in decision making process is consultation and joint planning for reopening with communities and education key stakeholders (Education during COVID-19 and Beyond 2020 United Nations)

Parent's perception on mitigation measures before reopening of learning institution after a pandemic has been considered to be a good concept given that, studies have majorly focused on parents as the decision maker. A study by Schueler, Mclntyre and Gehlbach (2017), where they were measuring parent's perceptions of family -school engagement, concluded that measuring parental engagement is deceptively challenging. This theory is consistent to this study, given that parents are more often indirectly get affected when decision of either closing or reopening places of learning is arrived at by sitting governments. They however play key role as major stake holders, and this therefore calls for their involvement in making their proposals to some key mitigation measures to be assured that satisfactory methods are put in place to enhance safety of their children.

A survey done by the University of Michigan on parents living in three different states noted that a third of parents would not be ready to send their children back to school because of COVID-19.This is so because they were not sure whether any substantive mitigation measures had been put in place(Phys.org, 2020,June, 26). Chua believed it was important to continue to survey parents regarding their plans and support for COVID-19 risk mitigation measures. "In our survey, parents expressed a lot of uncertainty regarding their plans for school attendance," he says. "Many are waiting to see how schools address safety and 
how the pandemic evolves. It's very likely that parents' views and plans will change as new information becomes available." Ibid.

Since COVID-19 pandemic has caused great disruptions of education systems in history by affecting about 1.6 billion learners in more than 190 countries in the whole world, Closing of schools impacted 94 percent of the world's student population and about 99 percent in low and lower middle income countries according to a report by United Nations(2020). In their conclusion, they regard listening to the voices of all concerned persons as a critical role which cannot be overlooked especially; parents, caretakers and teacher who have been instrumental since the onset of crisis. An essential part in decision making process is consultation and joint planning for reopening with communities and education key stakeholders.

\section{PROBLEM STATEMENT}

COVID-19 mitigation measures before and after reopening of learning institution has been a responsibility of the sitting governments with biased involvement of parents in decision making. When such happens, parent may feel left out and therefore lose confidence on the handedness measure by such institutions of learning. This could significantly reduce the number of the students expected to report back to school. By bringing parents on board therefore will ensure maximization and good utilization of government resources while at the same time enhancing children performances, a hypothesis supported in a study done by Diranian S.,(2017), looking at "How Lack of Parenting at Home Affect Children's Grades in School?"

\section{METHODOLOGY}

The study was done at KMTC-Mombasa using multistage sampling technique. Participants (parents) were selected randomly by convenient sampling technique. There was assumption that one student represented one parent. A $10 \%$ of the students population was used $(0.1 \times 850), n=85$. Out of this sample size, the ones who accepted to be interviewed were 73. An interviewer administered structured questionnaire was used. Data analysis was done using SPSS version 26. Presentation of the results was by use of tables, charts and narrations.

\section{RESULTS}

\section{Demographics of respondents}

Table 1: Distribution of Respondents by Age,

\begin{tabular}{|l|l|l|}
\hline AGE & Frequency & Percent \\
\hline $30-39$ years & 4 & 5.5 \\
\hline $40-49$ years & 25 & 34.2 \\
\hline $50-59$ years & 31 & 42.5 \\
\hline 60 years and above & 13 & 17.8 \\
\hline Total & 73 & 100.0 \\
\hline
\end{tabular}

Table 1 shows distribution in terms of age. A parent is any person who although not a biological parent, has parental responsibility for a child or young person. Age was defined as the length of time during which a person has existed. $42.5 \%$ (31) of the respondents were within the age group of 50-59 years, While $5.5 \%$ (4) are aged between 30-39 years, forming the least parent's respondents. It was not clear why the number of young parents was very low compared to the senior parents but this hypothesis is consistent with a 2019 census report, on Mother's mean age at first birth which was noted as 20.3 years (2014 est.) while the median age at first birth among women is 25-29years. This means for a child born to reach college level, the mother will be in her 40s. Secondly, cultural norms allow siblings to support each other's education hereby taking the role of a parent.

Table 2: Distribution of Respondents by gender

\begin{tabular}{|l|l|l|}
\hline \multicolumn{1}{|c|}{ GENDER } & Frequency & Percent \\
\hline Male & 40 & 54.8 \\
\hline Female & 33 & 45.2 \\
\hline Total & 73 & 100.0 \\
\hline
\end{tabular}

Table 2 shows distribution in terms of gender. Gender was defined as biological characteristic of being either male or female. $54.8 \%$ (40) of the respondents are male and $45.2 \%$ (33) female, a difference of $9.6 \%$ (7). This may support hypothesis that men in Africa still play critical role in decision making, according to Maseno and Kilonzo (2011), who in their wisdom viewed a system of male authority which oppresses women through its social, political and economic institutions. This therefore reveals more on how decisions are made in the African society, favoring male dominance.

\section{COLLEGE MITIGATION MEASURES TO PREVENT SPREAD OF COVID-19}

Measures were referred to the actions that the college would take to prepare for the resumption of college activities (before and after) while mitigation was referred to as specific preventive measures to minimize spread of COVID-19. Since parents are the major college or school financier, their involvement in the mitigation measures cannot be over emphasized. To address the 
above objective, parents were asked through structured questionnaire to highlight measures the college should take to maintain safety and prevent spread of COVID-19 before and after return to college. Results were as follows:

Table 3: Measures to be taken by the college before students resume college.

\begin{tabular}{|l|l|l|}
\hline Grouped response & Frequency & Percent \\
\hline Provision of information and education & 4 & 5.5 \\
\hline Stop quarantine activities and fumigate college & 21 & 28.8 \\
\hline Infection prevention measures(PPE, sanitizers and soaps) & 22 & 30.1 \\
\hline Screen and test all students before admission & 2 & 2.7 \\
\hline Restructure college to comply with GOK requirements & 24 & 32.9 \\
\hline Total & 73 & 100.0 \\
\hline
\end{tabular}

Table three shows mitigation measures to be taken before students resume college. $32.9 \%$ (24) of the respondents recommended restructuring of college to comply with the Government of Kenya guidelines while $2.7 \%$ (2) of the parents which is the least number, recommended screening and testing of the students before admission. These findings of $32.9 \%$ agrees with a study by Loyola University New Orleans on "college restructuring" that strongly recommend restructuring classes as way of preventive to COVID-19 and college development( Loyola University 2015). This study however negate findings of a study done by Gravatt J. (2018), on "College restructuring is complex, costly and shrouded in secrecy" drawing a conclusion that other methods can be explored before deciding to restructure a college.

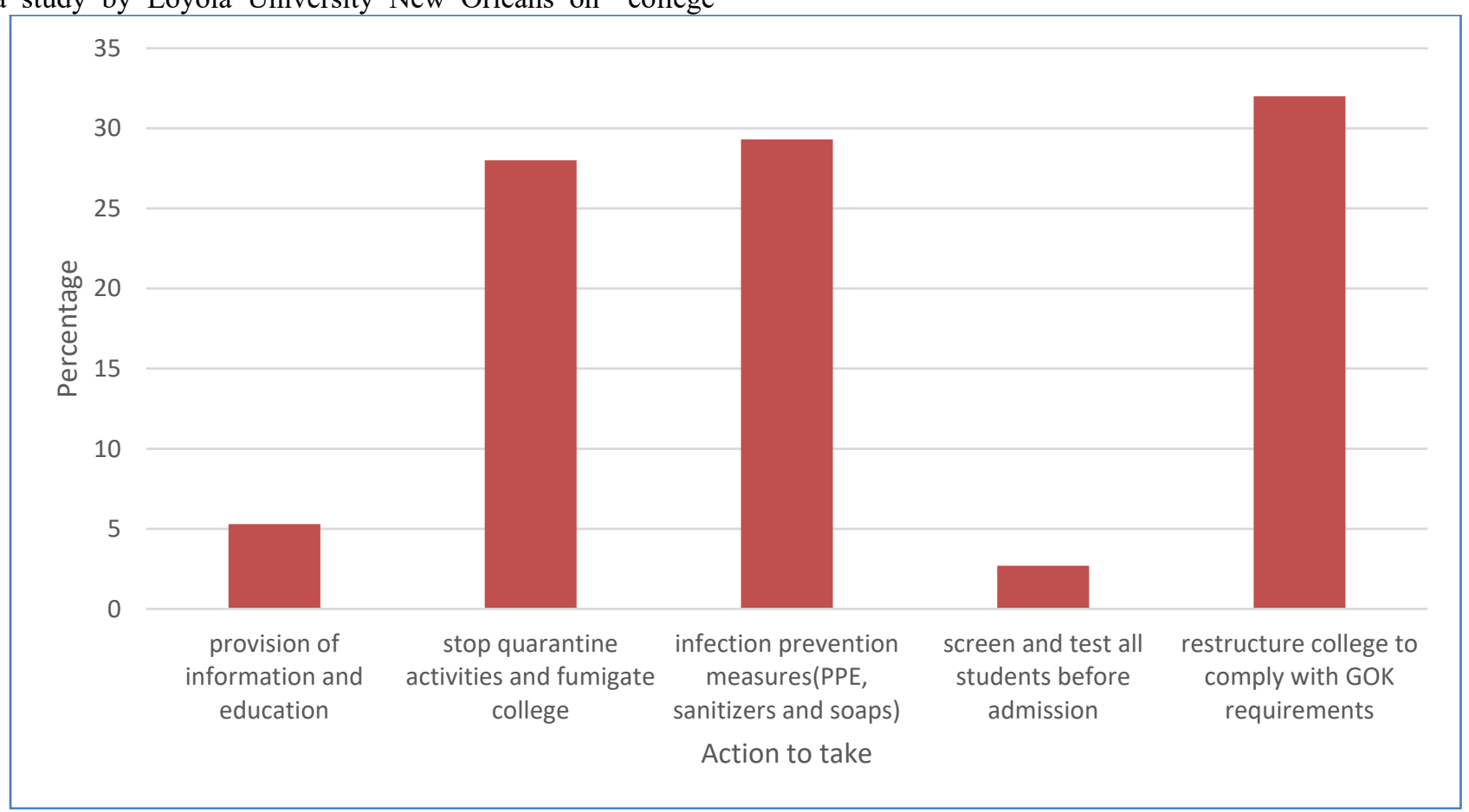

Fig.1: Mitigation measures before reopening of college

The figure above Shows pictorial presentation of mitigation measures to be taken against COVID-19 infection before reopening of college.

Table 4: Measures to be taken by the college after students resume college

\begin{tabular}{|l|l|l|}
\hline Coded responses & Frequency & Percent \\
\hline Cleaning and Fumigation of college & 4 & 5.5 \\
\hline infection prevention and provision of PPE & 35 & 47.9 \\
\hline Adhere to GOK guidelines & 21 & 28.8 \\
\hline provision of information and education & 7 & 9.6 \\
\hline screening and testing & 6 & 8.2 \\
\hline Total & 73 & 100.0 \\
\hline
\end{tabular}


Table 4 shows measures to be taken after students resume college. $47.9 \%$ (35) of the respondents suggested that the college should provide personal protective equipment (PPE). $5.5 \%$ (4) recommended the college to be cleaned and fumigated regularly which forms the least number of the parents. This data correspond to a study by center for Disease Control and Prevention (CDC, 2020) which proposed regular supply of PPE to students while in college to reduce chances of disease spread.

\section{DISCUSSION}

The World Health Organization declared COVID 19 as a Public Health Emergency of International Concern leading to closure of learning institutions and social gatherings. Several public health measures were proposed to prevent and control transmission of COVID-19. A part from closure of learning institutions according to Blanco \& Lurye (2020, July, 30), these included case identification, contacts tracing and case isolation, environmental disinfection and use of personal protective equipment (WHO, 2020). The implementation of case isolation led to conversion of several learning institutions in Kenya into COVID-19 quarantine centres to focus on triaging and sorting of suspected contact clients. Kenya Medical Training College Mombasa was among the quarantine centres.

Several reports agreed with our study. A report by Neil Campbell (2020, Sept., 21) on Vouchers over Virus: How the Department of Education Prioritized Private School Vouchers Over Responding to COVID-19, agreed with Table 4 above, where parents were lamenting how the Virus had forced closure of learning institution while at the same time making them think best mitigation measures before reopening of school. In their proposals, they suggested creation of budget to carter for necessary technology and personal protective equipment (PPE) to students and staff, to enhance retention of students and educators. The study had limitations on accessing adequate literature on mitigation measures to facilities that had been converted into quarantine centres. Despite parent's involvement on the matter of reopening, the end decision was found to still remain with the implementers who in this case being either the government or the school proprietors.

In conclusion, there was clear need to implement preventive measures before and after resumption of the college activities to optimize on controlling the spread of COVID -19. It is equally important to involve parent's input in order to build their confidence on safety of their children.

\section{CONCLUSION}

Parents are key stakeholders in matters pertaining students learning. Their contribution therefore forms a critical part in creating self confidence that their children would be safe once they report back in college. College restructuring and infection prevention measures have to be in place before and after reopening of college, this would ensure high confidence in parents that their children shall be safe while they are within the learning institution.

\section{Recommendations:}

1. College Management should implement proposed measures before resumption of learning activities.

2. After students have resumed, preventive measures should be adhered and maintained to ensure their safety.

3. Further study to be carried out understand parents' fear on existing health and safety measures in places of higher learning in relation to a pandemics.

\section{REFERENCES}

[1] Blanco A. \& Lurye R. (2020). Who decides when schools close if students, staff contract coronavirus or cases spike locally? Superintendents seek guidance from state. Retrieved from; https://www.courant.com/coronavirus/hc-news-coronavirus-districtreactions-20200731-ibu3lajtuzdqfjczbgggwxyhve-story.html

[2] Campbell N.(2020). Vouchers Over Virus: How the Department of Education Prioritized Private School Vouchers Over Responding to COVID-19: Center for American Progress. Retrieved from; https://www.americanprogress.org/issues/education-k-

12/news/2020/09/21/490621/vouchers-virus-department-educationprioritized-private-school-vouchers-responding-covid-19/

[3] Diranian S.,(2017, June, 13). How Does a Lack of Parenting at Home Affect Children's Grades in School? Halthfully. Retrieved from https://healthfully.com/537890-how-does-lack-of-parenting-at-home-affectchildrens-grades-in-school.html

[4] Gravatt J.( 2018). College restructuring is complex, costly and shrouded in secrecy. Learning curve group. Retrieved from https://feweek.co.uk/2018/11/19/college-restructuring-is-complex-costlyand-shrouded-in-secrecy/

[5] Kenya Census (2019). Kenya Demographic Survey. Retrieved on 2020, Sept. 28th, from https://www.indexmundi.com/kenya/demographics_profile.html

[6] Loyola University New Orlans (2015).College Restructuring; Office of Academic Affairs. Retrieved from http://academicaffairs.loyno.edu/collegerestructuring

[7] Maseno L., \& Kilonzo S.M. (2011). Engendering development: Demystifying patriarchy and its effects on women in rural Kenya. International Journal of Sociology and Anthropology Vol. 3(2) pp. 45-55, February 2011 From: https://academicjournals.org/journal/IJSA/article-fulltext-pdf/01883E11988

[8] Retrieved from https://www.courant.com/coronavirus/hc-news-coronavirusdistrict-reactions-20200731-ibu3lajtuzdqfjczbgggwxyhve-story.htm

[9] Schueler B., Mclntyre J., \& Gehlbach H.(2017). Measuring Parent Perceptions of Family-School Engagement: The Development of New Survey Tools. School Community Journal, 2017, Vol. 27, No. 2275 Available at http://www.schoolcommunitynetwork.org/SCJ.aspx

[10] University of Michigan.(2020). 1/3 of parents in 3 states may not send children to school because of COVID-19. Retrieved from https://phys.org/news/2020-06-parents-states-children-school-covid-.html

[11] UNITED NATIONS 16). Optimizing PPE Supplies. Healthcare Workers. Retrieved from https:/www.cdc.gov/coronavirus/2019-ncov/hcp/ppestrategy/index.html

[12] United Nations Retrieved on 21/09/2020 from https://www.un.org/development/desa/dspd/wpcontent/uploads/sites/22/2020/08/sg_policy_brief_covid19_and_education_august_2020.pdf

\section{AUTHORS}

First Author - Garama Mramba, Bachelors, KMTC, cgarama@kmtc.ac.ke

Second Author - Jeniffer Mwema, Bachelors, KMTC, jmwema@kmtc.ac.ke

Third Author - Rachael Mwende, Bachelors, KMTC, rmusyoka@kmtc.ac.ke 
Fourth Author - Florid Ogall, Bachelors, KMTC, fogall@kmtc.ac.ke

Fifth Author - Lucas Ruwah, KMTC, lruwah@kmtc.ac.ke
Correspondence Author - Garama Mramba, Bachelors, KMTC, cgarama@kmtc.ac.ke, +254713939711 